\title{
Paraganglioma-Like Dermal Melanocytic Tumor
}

National Cancer Institute

\section{Source}

National Cancer Institute. Paraganglioma-Like Dermal Melanocytic Tumor. NCI

Thesaurus. Code 137258.

\begin{abstract}
A benign primary melanocytic tumor of the skin that presents as a dermal nodule.
Morphologically, it is characterized by the presence of parag ang lioma-like features that include a nested growth pattern of the tumor cells. The nests are composed of epithelioid cells and are separated by delicate fibrous strands. Cytoplasmic melanin is not present; however immunohistochemical studies have confirmed the melanocytic lineage of the tumor cells.
\end{abstract}

